\title{
ALGUNS ASPECTOS DA INFLUÊNCIA FRANCESA ÉM SÃO PAUlo NA SEGUNDA METADE DO SÉCULO XIX
}

Na história da cultura brasileira há um momento em que ela passa direta e nitidamente a sofrer influência da cultura francesa. Essa época é o século XIX. Durante anos e anos, inúmeros traços foram acrescentados à vida brasileira graças aos contactos com homens, costumes, idéias e coisas de procedência francesa. Os velhos jornais, o relato de viajantes que percorreram o país nesse período e as memórias da época, oferecem excelente documentação que atesta a importância dessa influência, consignando, por vêzes choques com outras, sobretudo a inglêsa (1). Esta, reflexo do predơmínio econômico da Inglaterra, manifestou-se na vida cotidiana, imprimiu traços na paisagem urbana, refletiu-se no campo político e ideológico. Ela teve o seu historiador - Gilberto Freyre. Em sua obra Inglêses no Brasil (2), procurou êle, fazer um inventário do muito que assimilamos dos inglêses, desde o uso do chá, da cerveja, até o bife com batatas, a residência em subúrbio, o juri e o habeas corpus .

Não foi menos importante a ação da França. Embora não tivesse o desenvolvimento da Inglaterra, cujo progresso econômico não podia acompanhar, foi sempre uma rival no Brasil a disputar-lhe a clientela comercial e o domínio dos espíritos (3). A sua contribuição para a cultura brasileira foi enorme e está a pedir um estudo semelhante ao que fêz o, autor de Casa Grande e Senzala sôbre a influência britânica: um estudo que analise a maneira pela qual se processou êsse fenômeno e os seus resultados. Pensando nisso, procuramos fazer algumas observações que sirvam como uma pequena contribuição para um estudo que algum dia se faça no sentido de preencher essa lacuna (4).

\footnotetext{
(1). - Caio Prado Jr. em sua obra Formação do Brasil Contemporâneo (3a. edição. Editôra Brasiliense) citando Martius, regista o choque entre a influência inglêsa e a francesa dizendo à pág. $376:$ - “... Martius observará o que ainda hoje, à primeira vista, nos parece um paradoxo: apesar do completo domínio comercial exercido pela Inglaterra, e do número muito maior de inglêses aqui domiciliados, a cultura franzesa nào sofreu concorrência.

(2). - Gilberto Freyre, Inglêses no Brasil, pref. de Otávio Tarquínio de Souza, pág. 17.

(3). - Ibidem, pág. 20.

(4): - Algo já foi feito nesse sentido em $U m$ engenheiro francês no Brasil, de Gilberto Freyre. Livraria José Olímpio Editôra, 1940. Nesse trabalho, entretanto, o autor não analisa "como fêz no estudo sôbre a influência britânica" os resultados da influência francesa no Brasil.
} 


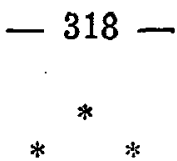

A influência francesa esteve presente no Brasil durante todó o século XIX, acentuando-se sua importância com o passar dos anos. O resultado foi surgirem já no fim do século homens como Santos Dumont e Antônio Prado, para citar apenas dois dos mais significativos nomes da época, verdadeiros representantes do espírito francês, vivendo em ambiente brasileiro. Não constituiram êles exceção dentro de seu tempo, como se poderia imaginar, mas representaram tôda uma geração que se formou segundo os moldes franceses.

Na história da influência francesa no Brasil, é sem dúvida, o século XIX, o mais importante pelos seus resultados. Vivera a colônia nos três primeiros séculos relativamente segregada da Europa não ibérica, principalmente nas regiões de maior especialização econômica e intensa endogamia". (5) onde se definira uma "paisagem social com muito de asiático, de mourisco" e por vêzes de africano (6). Dessa forma, a colônia portuguêsa na América se revestira de aspectos tão exóticos" do ponto de vista europeu" (7) que o século XIX, promovendo o contacto direto do Brasil com a Inglaterra e com a França, depois da vinda da côrte portuguêsa, teve para ela o caráter de uma europeização num sentido diverso do português $(8)$.

O contacto maior da colônia, e mais tarde do Império, com as idéias e costumes dêsses pases estrangeiros, muito modificou o panorama da antiga sociedade colonial, impondo-lhe novos hábitos, criando-lhe novas necessidades.

Até então, as influências francesas ou inglêsas chegavam ao Brasil, fraca e indiretamente, através de Portugal, com raras exceções em um ou outro ponto do Brasil onde houve intercâmbio direto com inglêses e franceses. Esses primeiros contactos reportam-se aos primórdios da colonização. Inicialmente aqui aportaram os contrabandistas de madeira, na maioria de Honfleur e de Dieppe (9). Depois dêsses, alguns aventureiros franceses, como Villegaignon e la Ravardière, procuraram estabelecer uma colônia de França no Brasil. Viajantes, cientistas, missionários franceses, como Lery, Thevet, Claude d'Abeville, piratas como Du-

\footnotetext{
(5). - Gilberto Freyre, Sobrados e Mucambos. Biblioteca Pedagógica Brasileira. Editóra Nacional, 1936, pág. 257.

(6). Ibidem, pág. 258 .

(7). - Ibidem, págs. 258-259

(8). - Ibidem, pág. 271.

(9). - G. Freyre em sua obra $U m$ engenheiro francês no Brasit à pág. 22, refere se a êsses primeiros contactos dizendo: "Os produtos das primeiras ativi. dades françesas no Brasil foram as madeiras de contrabando. Das subprodutos interessam particularmente ao estudioso da formaçāo social do Brasil nos seus pontos de contacto com a França, aquêles mestiços arruivados e aquela provável difusäo de miudezas de arte ou de objetos de fabrico francês que teriam marcado o início da influência da grande nação européia sôbre - nosso país. Influência de cangue e influência de cultura".
} 
gay Trouin, também aqui estiveram, antes do século XIX e favoreceram, cada um por sua vez, o intercâmbio com as coisas francesas. Entretanto, pela pouca duração e instabilidade dêsses contactos, pelo seu caráter esporático, sua contribuição foi pequena, não deixando marcas muito evidentes na cultura brasileira, limitando-se sua atividade a áreas muito restritas do nosso território.

Os pdrtos do Brasil permaneceram durante o período colonial fechados às nações estrangeiras, ao comércio e à imigrą̧ão. Sabe-se, no entanto, pelo depoimento dos viajantes e por denúncias do Santo Ofício, que alguns franceses, embora em pequeno número, conseguiram viver no Brasil antes do século XIX. Foram êles agentes divúlgadores da técnica e da cultura francesa no meio em que se estabeleceram.

Apesar da proibição da entrada de livros franceses durante quase tôda a época colonial (10), alguns espíritos mais esclarecidos, desde os fins do século XVIII, inspiravam-se diretamente nas obras francesas. Por outro lado, já nesse tempo algumas famílias brasileiras costumavam mandar seus filhos estudar em Faculdades francesas; de preferência em Montpellier (11). Começavam pois a intensificar-se no fim do século XVIII os contactos com a cultura francesa. Apareciam seus primeiros frutos em algumas regiões do Brasil. Num inquérito feito por Eduardo Frieiro (12) na biblioteca do cônego Luís Vieira da Silva, um dos espíritos mais instruidcs dentre os conjurados da Inconfidência Mineira, registou-se uma grande quantidade de livros franceses. Eram os pri. meiros sinais evidentes dessa influência entre nós, prenunciadores da grande importância que ela teria cinqüenta a cem anos mais tarde.

Referindo-se aos últimos quartéis do século XVIII, diz o mesmo autor?" "Tudo vinha da França, ou por via francesa. A hor: $\mathrm{da}$ América era nos dada pelo meridiano de París" (13). Essa inflência ficava, entretanto, restrita a um núcleo muito pequeno, a um grupo de pessoas excepcionais para sua época. Limitava-se também essencialmente ao campo das idéias. A vida cotidiana mantinha seu aspecto tradicional, ainda não fôra abalada pela importação de objetos e costumes franceses.

Era êsse o quadro até 1808 quando, com a vinda de D. João VI para o Brasil, o papel da influência francesa, até então pouco significativo, mudará completamente. A côrte portuguêsa trazia consigo hábitos de luxo europeu (14) e para satisfazer êsses costu-

\footnotetext{
(10). - A êsse respeito veja-se G. Freyre, op. cit, pág. 33 e 34 . Eduardo Frieiro, O diabo da livraria do Cônego, pág. 18.

(11). - Já era grande no fim do século XVIII o número de brasileiros que iam estudar na França. Caio Prado em sua obra, Formação do Brasil Contemporâneo, vol. I, referindo-se ao último quartel do século XVIII, assinala a presença de muitos brasileiros em Montpellier. (pág. 363).

(12). - Eduardo Frieiro, $O$ diabo na livraria do Cónego, Livraria Cultura Brasileira. Belo Horizonte, 1945.

(13). - Ibidem, pg. 58 .

(14). - Jean Debret, Viagem pitoresca e histórica ao Brasil. Livraria Martins, pg. 139.
} 
mes que se tornaram necessidades, vieram com ela cabelereiros e modistas franceses e comerciantes inglêses. Finalmente, com a abertura dos portos, homens e coisas, de origem estrangeira puderam penetrar livremente. Logo de início predominaram as influências britânicas. Era natural! A Inglaterra ajudara o príncipe regente e a côrte a escapulirem-se para o Brasil, e a França, na figura de Napoelão, tornara-se sua inimiga. Como recompensa pela sua proteção aquela obteve o tratado de 1810 pelo qual os produtos inglêses passaram a pagar $15 \%$ de tarifa, enquanto os de Portugal pagavam $16 \%$ e os dos demais países $25 \%$ !

Com êsse incrível tratado que os privilégios da situação política the haviam assegurado, firmou-se a preponderância comercial da Inglaterra no Brasil e paralelamente o predomínio da ínfluência inglêsa em quase todos os setores (15). A influência francesa foi momentâneamente eclipsada e a Inglaterra "deu a nota" de 1808 a 1815 . Só após 1816 voltaria a França a fazer-lhe concorrência, a desafiar-lhe o prestígio!

A situação política mudara. Napoleão, o inimigo de D. João VI, havia sido derrubado, os Bourbons recolocados no trono. As resoluçôes do Congresso de Viena contribuindo para o apaziguamento gradual dos ânimos e a dissipação das prevenções, propiciaram à influência francesa total acolhimento no Brasil (16). Nos conselhos da corôa, à política anglófila de Linhares sucederam as tendências francófilas do Conde da Barca. Estreitaram-se as relações entre os dois países. D. Jcão VI ao enviar um €missário seu saudar Luiz XVIII (17) oficializa a cordialidade entre o Brasil e a França, consolidando definitivamente o predomínio da sua influência. $\mathrm{O}$ príncipe concretiza seu interêsse em estreitar êsses laços, convidando para vir ao Brasil ilustres membros do pensamento francês: Lebreton, Debret, Montigny, Taunay, Ferrez, que constituiram a famosa missão artística de 1816 .

Varridos os impecilhos, até então existentes, homens, livros, idéias e coisas de procedência francesa, penetram em larga escala nos meios brasileiros. Obras francesas inundam as livrarias. A língua é amplamente divulgada entre nós. Multiplicam-se as viagens de turismo. Comerciantes de todos os ramos, artezões de tôdas as profissões, técnicos, professôres, colégios de religiosos franceses aqui fundados, sábios e viajantes, refugiados políticos, que aqui aportaram em virtude das sucessivas agitações revolucionárias em França, entram a influir poderosamente "com sua técnica com seu gôsto", com os artigos que importam ou confeccionam, com sua.

\footnotetext{
(15). - Wanderley Pinho, Salöes e Damas do 2." Reinado. Livraria Martins, 2a. ediçэัo, pg. 17

(16). - Pedro Calmón em História Social do Brasil. Cia. Editôra Nacional, 3a. edição. Tomo I, pg. 291, observa: "A política de influência de D. João VI graças aos seus entendimentos com a Austria e com a França orienta para as coisas francesas o interêsse e a curiosidade do Brasil.

(17). - Mario Lima Barbosa em Les Français dans l'Histoire du Brésil. París, Librairie Scientifique Albert Blanchard, pg. 218.
} 
maneira de viver e de pensar enfim, sôbre a vida, os costumes e as idéias da sociedade brasileira (18). Daí por diante a nossa mentalidade afinou-se pelas cordas francesas, e essa influência, durante algum tempo obscurecida pela inglêsa, passou a dominar quase soberana. "Linhares quisera ser um Pitt, ou um Canning, Pedro I sonhou ser um Bonaparte. A Lecor, discípulo de Wellington nas fileiras do Brasil, vai suceder Labatut, discípulo de Massena. Ao economismo inglês de 1808 , o regime unitário monárquico de 1824 copiado da doutrina de Benjamin Constant. Depois de 1816, o povo continuou a comprar a Londres mas a imitar París" (19).

Essa influência não se manifestou nem com igual intensidade, nem simultâneamente em todo o Brasil. Sua ação foi maior em alguns núcleos como Rio de Janeiro, Pernambuco, Bahia, São Paulo, onde os vários agentes colaboraram nesse sentido. No Rio de Janeiro, em Pernambuco e na Bahia essa influência já estava amadurecida e manifestava-se em tôda sua plenitude desde a primeira metade do século XIX. Nessa mesma época, em São Paulo, ela apenàs se esboçava e só alcançaria igual importância, cinqüenta anos mais tarde.

Em Pernambuco a divulgação dos costumes franceses era tal que um jornal de 1842 publicava os seguintes versos:

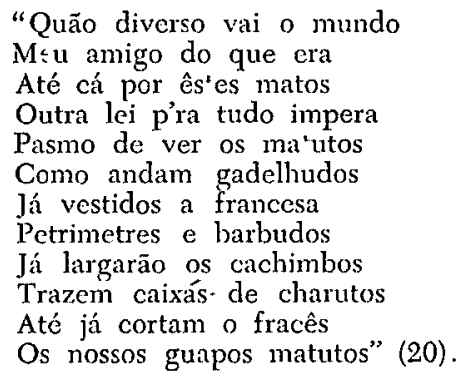

Nessa mesma época $O$ Carapuceiro, outro jornal de Pernambuco, dizia: "Tudo se quer à francesa" (21).

Era o mesmo no Rio de Janeiro onde na côrte de Pedro I, principalmente depois do seu casamento em 1829 com a princesa Amélia de Leutchemberg, filha do príncipe de Beauharnais, era bom tom falar-se ùnicamente o francês (22), ataviar-se ao gôsto francês; discutir-se idéias francesas; enquanto o empertigado regimento de granadeiros e infantes alsacianos e suiços que compunham a guarda de $\mathrm{D}$. Pedro I, distribuia-se aqui e ali comandado por oficiais franceses, ostentando o uniforme e o aspecto marcial

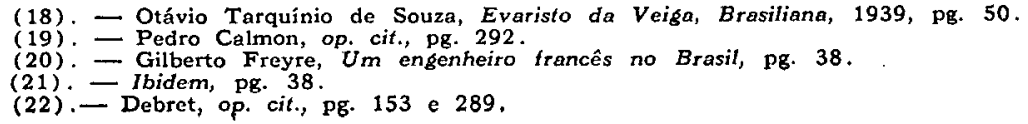


dos exércitos napoleônicos, dos quais haviam feito parte (23). No Rio de Janeiro o povo extasiava-se diante da vitrinas das ca." sas de comércio francesas, da rua do Ouvidor, tantas vêzes comparada pelos viajantes à rua Vivienne em París (24). Enquanto isso, em São Paulo, apenas um cu outro francês pioneiro estabelecia-se como hoteleiro ou dono de casa de jóias, e êsses mesmos podiam se contar nos dedos de uma das mãos (25).

Os cronistas que percorreram o Brasil nessa época, espantamse diante dessa diferença "chocante" entre São Paulo e as cidades do Rio de Janeiro ou Recife. A influência francesa na Paulicéia permanecia restrita ao âmbito, muito fechado, das salas da Faculdade de Direito, atuando quase exclusivamente no campo das idéias. Só foi adquirir importância em São Paulo na segunda metade do século XIX. Enquanto em outras regiões ela amadurecia, aqui se achava apenas no embrião. Com igual atraso em relação à outras partes do Brasil aqui chegou a influência britânica. "Acentuou-se já no fim do segundo Reinado e começo da República, quando principiou a declinar na maior parte do Brasil, principalmente naqueles pontos - Rio, Bahia e Pernambuco, onde chegara a ser nada menos que imperial" (26).

São Paulo parecia menos penetrável às influências estrangeiras. Como explicar o fenômeno? Várias foram as conđições que contribuiram para que a influência francesa penetrasse antes no Rio de Janeiro e em Pernambuco e só posteriormente em São Paulo . Recife e Rio de Janeiro contavam com a vantagem de serem portcs de mar de grande movimento, e sempre em contac- to $\mathrm{ccm}$ vapores vindos da Europa. Possuiam uma população muito maior, cujo poder aquisitivo era nitidamente superior ao do paulista, e que se habituara a um nível de vida mais elevado. $R$ zcife, vivia ainda na tradição da riqueza do açúcar e o Rio possuia o exemplo da vida de luxo da côrte. Para êsses pontos afluiram के artistas engenheiros, comerciantes, artesõ $€$ - franieses atraídos pelas grandes possibilidades que a vida nesses lugares se lhes oferecia. Nessa época ninguém se lembraria de vir para São Paulo onde a população era pequena, de hábitos modestos e isolada pela deficiência dos meios de transportes que dificultava qualquer tipo de comércio! Era no Vale do Paraíba, nos solares das fazendas de café que pontilhavam essa via natural onde.se respirava um pouco da atmosfera francesa.

Pode se escolher como marco da definitiva penetração da influência francesa em São Paulo, a fundação em 1860 da Casa

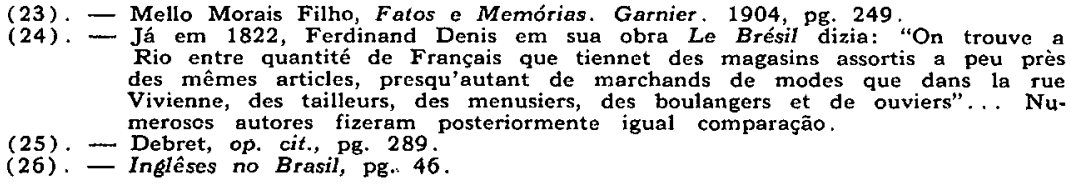
Rio entre quantité de Français que tiennet des magasins assortis a peu près des mêmes articles, presqu'autant de marchands de modes que dans la rue Vivienne, des tailleurs, des menusiers, des boulangers et de ouviers"... Numeroses autores fizeram posteriormente igual comparação

(25). - Debret, op. cit, pg. 289

(26). - Inglêses no Brasil, pg. 46. 
Garraux: livraria, tipografia, depósitos de vinhos, de guarda-chuvas, objetos de artes, etc... e que durante muitos anos desempenhou papel de importante centro difusor da cultura francesa. A partir dessa data observa-se em São Paulo a mesma procura pelos livros franceses, a mesma afluência de comerciantes e técnicos franceses, que se assinalara no Rio, Bahia ou Pernambuco, já na primeira metade do século XIX. A sociedade paulista "afrancesava-se" como as suas irmãs e embora um pouco tardiamente, identificava-se com elas. Dai para diante a influência francesa $\in \mathrm{m}$ São Paulo cresceu sempre em intensidade, atingindo seu climax com o desenvolvimento da cultura cafeeira e a melhoria dos meios de transportes no fim do século, quando fortunas brilhantes levaram para a Europa famílias inteiras de fazendeiros, quando os filhos dêstes, freqüentando as Universidades da França, ao voltarem traziam consigo a insatisfação e o desêjo de transplantar para sua terra, suas fazendas, suas casas, um pouco do ambiente francês que tanto thes agradara e ao qual se haviam acostumado.

Eduardo Prado, nítido expoente dessa geração, transporta para sua fazenda "Brejão", no município de Casa Branca "as suas comodidades de París". "Brejão é uma proeza do espírito, do espírito paulista que traz a Europa para os cafezais" (27).

A riqueza proporcionada pelo café permitiu aos paulistas, mais do que nunca, entrarem em contacto com a cultura francesa e assimiliarem-na em grande parte. Se concretizássemos a evolução da influência francesa em São Paulo, num gráfico, observaríamos que esta no início quase nula, cresceria sempre no decorrer do século.

O conhecimento de alguns dós principais agentes responsáveis pela difusão da cultura francesa entre nós ajuda a esclarecer, em parte, o processo pelo qual se difundiu a influência francesa em São Paulo.

O papel desempenhado pelo que se costumou chamar de agentes técnicos (28) foi considerável, muito maior do que é costume avaliar-se. A melhor fonte de infcrmações para o estudo dêsses agentes, são os jornais da época. Seus anúncios nos permitem reconstituir um quadro bem próximo da realidade (29). Registam êlẹs a existência de um grande número de casas comerciais, e de artesões franceses em São Paulo, na segunda metade do século XIX. Estabelecimentos comerciais de propriedade ou pelo menos de nome franceses havia-as em todos os ramós de negócios. Predominaram talvez, no setor da moda. A casa $A u$ Bon Diable, Le Printemps, Lourise Paris, ou a casa de Augusto Corbisier, disputaram entre si, a clientela, importando artigos diretamente de París.

\footnotetext{
(27). - Pedro Calmon, op. cit., 3o. vol., pg. 188.

(28). - Gilberto Freyre na sua obra citada emprega essa expressão.

(29). - Muitos estudos tem sido feitos utilizando-se os jornais como documentos: entre êssęs destacam-se os de Otávio Tarquínio de Souza e os de G. Freyre.
} 
Augusto Corbisier, em anúncio de 24 de novembro de 1878 , no Correio Paulistano, participa aos fregueses, tanto da capital como do interior, que acabava de chegar um grande sortimento de roupas brancas, enxovais, vestidos, leques, grinaldas, véus, chapeus, flores, fazendas, etc., "comprado pela sua senhora mesmo em París". Au Bon Diable anuncia que "acaba de receber de París um grande sortimento" de costumes (30).

Também no ramo dos calçados dominam os comerciantes ou artigos franceses. A Bota Parisiense, anuncia em 13 de maio de 1878, no Correio Paulistano que "acaba de receber pelo paquete francês Ville Rio De Janeiro, ùltimamente chegado ao porto de Santos", um esplêndido e completo sortimento de calçados.

A palavra "París" torna-se verdadeiramente prestigiosa (31).

Se há um grande número de comerciantes franceses no setor das modas, sua importância não é menor em outros gêneros de atividade. Os brinquedos das crianças vêm da França. A Paradis des enfants, da viúva Genin e filhos, uma das grandes casas de brinquedos, em anúncio de 10 de novembro de 1878 , notifica ao público paulista a chegada de variado sortimento de brinquedos, "tudo comprado e escolhido em París, por um dos sócios da casa ùltimamente chegado".

O comércio dos livros está quase todo em mãos de franceses. E' na livraria Larroque, na Casa Garraux, ou na Imperial litografia de Jules Martin, que se compram as obras-primas da literatura francesa. Mesmo no ramo da indústria aparecem êles (açambarcando o mercado), tal é o caso da Distillerie Française, fundada em 1868 (32). As únicas tinturarias existentes estão na mão de franceses (33). E' na mão de um dêles Henrique Levy, que está o monopólio da importação de artigos musicais. Franceses também são os que dominam o mercado de jóias como Pedro Chiquet, ou Suplicy.

Os anúncios que se sucedem demonstram de maneira a não deixar dúvidas a proeminência dos artigos franceses no comércio paulista.

As casas comerciais em São Paulo, na segunda metade do século XIX, distribuem-se aproximadamente em dois grupos: as francesas e as nacionais, na maior partes das vêzes também importadoras de artigos caracterìsticamente franceses a que se vem obrigadas não só pela falta de produtos nacionais como para não sucumbir à concorrência. Um exemplo: "O Cangirão Monstro, que oferece ao público um variado e completo sortimento de louças, porcelanas, cristais, talheres, cristophle 'colares anodynos ele-

\footnotetext{
(30). - Anúncio no Correio Paulistano, de 29 de outubro de 1878

(31). - Charles Expilly, Le Brósil tel qu'il est. Paris. 1862, pg. 271.

(32). - A Distillerie Française foi fundada em 1868 por Mr. Bolidair, e aparece em anúncios sucessivos nos jornais da época.

(33). - Em 1878, a 30 de janeiro, aparece o anúncio da Tinturaria Francesa situada na Rua da Imperatriz e em 1871 a Tinturaria Drat et Bonnet.
} 
tro-magnéticos de Royer, para facilitar a dentição e evitar as convulsões das crianças, e as excelentes maquinas Lhôte, para água Selts' recomendadas, como as mais simples, bonitas e baratas para - fabrico dêsse líquido tão útil na estação calmosa", e que recebe todos os seus artigos da casa matriz na Côrte, a qual por sua vez, recebe tudo "diretamente da Europa" (34).

A mais célebre das casas comerciais na mão de franceses estabelecidos em São Paulo, na segunda metade do século XIX, é a casa Garraux.

Começara Mr. Garraux em 1859 com uma quitanda, onde vendia, além de papéis para cartas, penas, lapis e outros artigos de escritório, números das revistas: Illustration e Monde Illustré (35). Já em 1860 funda a casa que teve o seu nome. "Espírito progressista, Mr. Garraux, assinalou desde logo sua presença na Paulicéia por uma inovação no objeto de seu comércio - foi o introdutor do envelope" (36). Durante anos funcioncu a sua casa como importante centro de difusão da cultura francesa na sociedade paulista. Nos anúncios que publica nos jornais, desde o ano de sua fundação, aparece tôda sorte de produtos importados da França: "medicamentos homeopáticos da afamada casa Castellan e Irmãos de París (37), espelhos, quadros, jarras de porcelana, bronze, cristal, adornos de salas de visita, mesas de charão, aparadores, secretárias (burreau de dames), prateleiras, cachepots, vide poches, chifoniers, etc. Gravuras para quadros, caixas de costuras, envelopes, papéis fantasias para presentes, albuns de retratos, objetos de escritório, confeitos, brinquedos comprados na exposição industrial de París (38), etc. Além dêsses artigos, das mais variadas espécies, inúmeros outros que seria longo enumerar, eram encontrados na Casa Garraux. Era também livraria e aceitava assinaturas para jornais e revistas franceses (39).

Fundada em 1860 a livraria Garraux, tornou-se desde logo o centro elegante procurado pelos jovens intelectuais paulistas (40). Ali se reunia em longas palestras com Mr. Garraux, o melhor da intelectualidade paulistana, continuando a tradição estalebecida no Rio de Janeiro já na primeira metade do século XIX, onde, nas lojas de maior nomeada estacionavam habitualmente durante a semana, políticos, fazendeiros, diplomatas e funcionários públicos, em amistosa palestra (41).

Muitas amizades fêz o livreiro e agiu com sua casa de negócios, com os artigos que vendia e principalmente com sua marcan-

\footnotetext{
(34). - Corseio Paulistano de 12 de novembro de 1878 ; idem de 8 de janreio de 1878 .

(35). - Almeida Nogueira, A Academia de São Paulo. Tradiçóes e Reminicências 8 volumes. Tipografia Vanorden. 1907, vol. V, pg. 144

(36). - Almeida Nogueira, op. cit., vol. V, pg. 144.

(37). - Correio Paulistano de 30 de janeiro de 1878

(38). - Correio Paulistano de 17 de feverciro de 1878

(39). - Correio Paulistano de 5 de janeiro de 1878

(40). - Um idealista Realizador - Barāo Geraldo de Resende. Oficina Gráfica do Almanaque Laemmert. 1939, pg. 103 .

(41). - Mello Morais Filho, Fatos e Memórias. Garnier. 1904, pg. 249.
} 
te personalidade e cultura, como ativo agente da influência francesa entre nós.

Ao lado dessas casas comerciais, algumas das principais entre muitas outras que seria fastidioso enumerar, anunciadas não só em jornais como nos almanaques da Província de São Paulo e que denotam a importância adquirida pelos comerciantes de origem francesa, alinham-se os nomes de artesões, especialistas franceses de tôdas as profissões.

Vários são os cabelereiros. Ao que parece êsse gênero de atividade estava exclusivamente nas mãos de franceses, como Aimé Quilliet, que em 3 de fevereiro de 1878 avisa ao público, através do Correio Paulistano, que acaba de chegar a sua casa "um dos mais hábeis cabelereiros de París que tem vindo ao Brasil" (!), Pedro Teyssier, Henri Biard, Bosignon e Pruvot (42) dominaram a arte entre 1865 e 1877 . Por volta de 1884 encontramos Guntimé e Husson. Sucediam-se assim os cabelereiros franceses em São Paulo. Além de exercer a arte, êles a ensinavam. Muitas familias paulistas, principalmente as residentes no interior, mandavam suas escravas aprender com os mestres franceses a técnica do penteado.

Numerosas são as costureiras e alfaiates franceses radicados em São Paulo na segunda metade do século XIX :Mme. Hervieu, Mme. Martin, Mme. Pruvot, Mme. Rochat, Mme. Pascau, tôdas costureiras, "elegantíssimas parisienses tout a fait chics" (43). Muitos são os alfaiates como Jules Pourrailly, Henri Secerpelle e Pierre Bourgade (44). Êste último, num anúncio ilustrado com sugestivo croquis, onde se enlaçam os nomes do Brasil e da França, faz questão de publicar em 12 de fevereiro de 1878 que "São Paulo não tem nada mais a invejar da côrte, pois a casa de Pierre Bourgade recebeu um hábil contramestre de alfaiataria que acaba de chegar de París". E' êsse mesmo Pierre Bourgade que, não se contentando com os lucros de tão elegante especialidade (45), vende em sua casa flores das mais variadas espécies.

Ao percorrermos os jornais da época, observamos que os franceses predominaram não só na venda de artigos musicais, como no ensino da música. Um dos mais célebres, foi o prof. Giraudon, que ensinou piano em São Paulo por mais de 30 anos. Nessa época, ao lado das modinhas brasileiras, já em declínio, começam a aparecer numerosos anúncios de músicas francesas: fantasias, valsas, quadrilhas e outras músicas recém-chegadas da França.

Dentistas franceses também aqui se estabeleceram na segunda metade do século XIX, como o estimadíssimo Emile Vautier, cujo nome se perpetuou numa rua do Canindé (46). Célebres fo-

(42). - Paulo Cursino de Moura, op. cit., pg. 238.

(43). - Paulo Cursino de Moura, op. cit., pg. 238.

(44). - Almanaque da Província de Säo Paulo, 1884

(45). - Em anúncio de 10 de novembro de 1878 .

(46). - Paulo Cursino de Moura, op. cit., pg. 238. 
ram as parteiras, como Mme. Gourgues que se anuncia nos jornais de 1878 como "sucessora de Mme. Chameroy" (!) e posteriormente Mme. La Borde. "Verdadeiros elementos de renovação do meio", antes delas lamentàvelmente sujeito às "comadres", nem sempre hábeis, às "curicsas", nem sempre escrupulosas na higiene (47), ou às escravas de rudimentares conhecimentos.

Outra predominância francesa nos anúncios dos jornais paulistas da segunda metade do século XIX, é a de remédios, elixires e drogas as mais variadas. Não faltava a uma farmácia caseira o remédio de Le Roy, ou o Vinho de Marsa - tônico do Dr. Mcucelot, da Faculdade de Medicina de París - ou a poção anti-reumática do Dr. Vaumé. Esses remédios eram vendidos freqüentemente em farmácias; em muitas das quais o farmacêutico como o muito apreciado Camilo Bourroul, eram franceses. Ao que parece, foram êles introdutores dêsse gênero de comércio no Brasil, suas boticas substituiram as velhas lojas de barbeiros cnde, nos tempos coloniais, se aplicavam bichas, sangravam-se doentes, vendiam-se pós e pomadas (48).

Vários são os franceses que aparecem como hoteleiros ou donos de restaurantes. Nesse ramo do comércio êles se distinguiram no Brasil desde os primeiros tempos do Império (49). Há ainda arquitetos aqui radicados como Charles Peyrouton (50), e pintores como Jacques Loustalot, dignos representantes da técnica francesa.

$\mathrm{Na}$ arte fotográfica se notabilizaram. Os fotográfos nacionais anunciam muitas vêzes, a título de propaganda, a sua ida à França para se especializarem. Tal é o caso do Aviso publicado em 14 de março de 1878, pela casa Fotcgrafia Americana, que anuncia o fechamento de suas portas durante certo tempo, por ter o "proprietário dêsse estabelecimento de ir a París estudar os progressos de sua arte".

Muitos cutros "avisos", denotando uma grande variedade de ccupações: engomadeiras, ferradores, jardineiros, cozinheiros, encadernadores, fabricantes de carros, seges, armeiros, etc., poderiam ser destacados dos jornais e almanaques. Em todos os ramos do comércio havia comerciantes (51) e artesões franceses, os quais dominavam pela sua capacidade e técnica e que sabedores do apreço com que se cotavam os artigos e artesões de origem francesa, fazem questão de acusar a sua proveniência. Ora, são artigos recebidos "pelo último vapor, vindo diretamente de París" ou é "um

\footnotetext{
(47). - Gilberto Freyre. Um engenheiro francês no Brasil, pg. 53 .

(48). - Mello Morais Filho em sua cbra Fatos e Memórias refere-se a êsse fenômeno à pg. 240 .

(49) - Daniel Kidder quando aqui esteve em 1838 , mais ou menos, refere-se à única casa onde se podia obłer hospedagem, e que cstava sob a direção de "um tal Charles, francês" (pg. 173)

(50). - Correio Paulistano de 1878 .

(51). - Se na Paulicéia era assim, essa influência não se restringia ao centro urbano. O mascate, geralmente francês (D'Assier, pg. 164), levava-a até às fazendas.
} 
contramestre recém-chegado, que oferece seus préstimos"; ora são artesões que propalam sua nacionalidade francesa com orgulho: cozinheiro francềs, jardirieiro francês, arrumadeira francesa. Sente-se, através dêsses anúncios, o prestígio com que contam as coisas e as pessoas vindas da França. Todo artigo fica imediatamen.te valorizado se a êle ajuntar-se a rúbrica "vindo de París" (!). Todo artesão adquire especial prestígio se fôr francês.

Essa elevada consideração em que são tidos todos os artífices e objetos da França provocam como é de se esperar muita fraude ccmercial, muito abuso. O que acontece em outras partes do Brasil, em Pernambuco, no Rio de Janeiro, e que é assinalado com espanto por viajantes como Expilly (52), Mme. Toussaint Simon (53) e D'Assier (54), repete-se em São Paulo, mantidas as devidas proporções. Alguns europeus que sabem falar francês, tentam fazer-se passar por tal. D'Assier assinala a freqüência dêsses abusos, em 1867, dizendo: que de fois demandant a un de ces français improvisés, le nom de son departement, je l'ai entendu me répondre: Fribourg (!)" (55).

Há também por parte dos franceses no Brasil grande facilidade em se improvisarem mestres cu especialistas das artes mais disparatadas (56). Um auxiliar de cozinha em París, transformase aqui em grande cozinheiro, quando não em alfaiate ou fotógrafo! Por outro lado, muita coisa "encalhada" vem como artigo de última moda (57).

A quantidade de referências que aparece nos jornais dá uma idéia do grandè número de franceses estabelecidos na pequena capital. A colônia francesa adquirira grande importância, chegando mesmo a formarem-se várias sociedades, entre as quais a Sociedade Francesa de Socôrro Mútuc, para franceses ou filhos de franceses nascidos no Brasil, e a Sociedade 14 Juilet, fundada $\epsilon \mathrm{m}$ 1881, pelos então magnatas da colônia francesa: Cahen Levy, B. Portier, J. Tallout, Rivière, Bourgard, Bolidair, etc. (58).

A colônia chegou mesmo a manter jornais como o muito conhecido Le messager, onde questões brasileiras, e assuntos franceses (59) eram analisadas lado a lado; e mais para o fim do século o órgão hedomadário L'Eclaireur" de Louis Viollet (60).

(52). - Charles Expilly, Le Brésil tel qu'it est. E. Den. París. 1862, pg. 270.

(53). - Mme. Toussaint Simon, Viagem de uma Parisiense ao Brasil. Tip. de Villeneuve. 1883

(54). - Adolphe d'Assier, Le Bresil Contemporain. París. Durand et Lauriel. 1867, (55) $161,164,165$

(55) - Tbidem, pg. 166 .

(57). - Os abusos atingiram tal proporção no Rio de Janeiro, quando da vinda dos primeircs franceses para o Brasil, que se tornou sinônimo de trapaça, dizerse "negócio afrancesado". como atesta Charles Expilly, op. cit., pg. 270 e D. Assier, op. cit., pg. 257

(58), - Paulo Cursino de Moura, op. cit., pg. 238.

(59). - Mario Lima Barbosa, op. cit, pg. 439

(60): - Afonso de Freitas, A Imprensa paulista, pg. 743 , in Revista do Instituto Histórico de São Paulo, vol. 6.0 . 
Êsses numerosos franceses, na sua maior parte simples co. merciantes, modestos artesões, contribuiram poderosamente para a evolução do pensamento e dos modos de vida em São Paulo (61). A importância que tiveram foi pressentida por um viajante que publicou em 1867, um livro sob o título: Le Brésil Contemporain, onde regista suas impressões. Observando o grande número de artesões e casas de comércio de patrícios seus aqui existentes, D'Assier divisando com argúcia a grande importância que tinham êsses elementos na difusão da cultura que representavm diz: “... cette population d'origine si incertaine a fait, au point de vue du progrès de l'influence française, plus que les frotes de la vieille monarchie, plus que tous les artistes et les savants venus a grand frais. Ce "mascate" (colporteurs) frippon, qui court les "fazendas" (plantations), avec ses caisses de faux bijoux, cette marchande de modes sur laquelle les voisins chochottent, sont des forces de propagande d'une puissance inimaginable; ... (62) E mais adiante ainda na análise do problema: Le français va au devant des brésiliens, les attire par sa verve gauloise et son interissáble gaité, aborde tous les questions, toutes les enterprises, n'est jamais a court pour trouver une solution aux affaites les plus impcssibles, répond en un mot a toute a force d'audace et d'entrain. Cette activité, cette bonne humeur, ces merveilles de l'industrie parisienne, agissent comme autant de couranltes magnetiques sur l'esprit des habitants et leur donnent a leur insu le desir de connaitre plus a fonde une civilization qui sait produire tant de choses, et un peuple de si attrayantes maniètes (63).

Nessas expressivas palavras está resumido todo o valor do papel desempenhado por êsses péquenos comerciantes e artesões aqui estabelecidos (64). Da sua atividade ficaram mais que traços materiais: alguma coisa do espírito e da cultura de cada um (65). Foram êles fontes de novos modos de vida para tôda uma sociedade. Agiram como centro de propagação da cultura francesa com a irradiação comercial de produtos, intelectual de idéias e principalmente social de costumes, usos e estilos de vida.

Portanto, "êsses contactos técnicos, na aparência os mais humildes, desempenharam um papel considerável nas relações francc-brasileiras consideradas habitualmente sob um ponto de vista exclusivamente intelectual e artístico e têm um grande interêsse

\footnotetext{
(61). - Gilberto Freyre em Um engenheiro francês no Brasil, pg. 16 acentua que mesmo os menos espirituais dos técnicos, como os cotinheiros e os padeiros, "também difundem sultura e modificam paisagens sociais".

(62). - Adolphe d'Assier, op. cit., pg. 261

(63). - Ibidem, pg. 262 .

(64). - Essa mesma idéia foi retomada por Otávio Tarquínio de Souza em seu livro, Evaristo da Veiga e por G. Freyre em $U m$ engenheiro trancés no Brasil, pg. 17.

(65). - No prefácio ao livro de G. Freyre acima citado, o prof. Paul A Bastide nota à pg. XXV: Mais les cas ne sont pas rares oú le français établi a l'étranger a su apporter a son nouveau pays tout le bênéfice de ses qualités et de sa culture d'origine.
} 
sociológico', principalmente se levarmos em conta que êsses dois aspectos da influência cultural estavam estreitamente ligados" (66).

Não menos importantes foi a atuação que tiveram os professôres, governantes, colégios e seminários na mão de franceses aqui estabelecidos. Exerceram êles no meio juvenil, que então se formava, poderosa influência e atração.

Inúmeras foram as governantes e principalmente as professôras francesas que se ligaram a famílias paulistas, tomando a seu cargo a educação dos jovens. Muitas vêzes residiam com as próprias famílias, passando quase a fazer parte das mesmas; outras -vêzes davam cursos particulares, como a estimadíssima Mme. Monfort, que entre 1878 e 1899, ensinou a crianças e moças das methores famílias paulistanas. Alguns chegaram a mandar vir diretamente da França professôres para educação de seus filhos. Esses mestres ensinavam aos jovens paulistas a língua francesa, geografia, história, aritmética, latim. $\mathrm{Na}$ quase totalidade dos casos, as aulas eram dadas em francês; daí uma divulgação cada vez màior da língua e consequientemente do pensamento francês. Da França também vinham todos os livros didáticos (66).

O espírito assim formado no interêsse pelas coisas francesas, ficava muitas vêzes mais conhecedor dêsses assuntos do que de temas brasileiros. Sugestivo é um trecho que encontramos no Tempo de Dantes, obra de uma paulista que viveu nessa época: Maria Paes de Barros. Diz ela: "enquanto a gramática francesa era decorada a fundo, limitava-se o ensino do português a minguados estudos no pequeno vclume da enciclopédia" (sic) (67). Fatos como êsses deviam repetir-se freqüentemente. Franceses aqui recém-chegados não podiam ter grandes conhecimentos da língua portuguêsa e dos assuntos brasileiros.

Era inevitável, nestas condições, que os jovens assim formados, desconhecendo os assuntos referentes à sua própria pátria e mais familiarizados com o sistema, com os assuntos franceses, ficassem para sempre ligados à França, intelectual e sentimentalmente. Esses mestres transmitiram aos alunos muito mais que o simples conhecimento de questões lingüísticas, históricas ou geográficas. Deram a êles uma contribuição muito mais valiosa: um pouco do seu espírito, do seu modo de encarar os problemas, do seu método, da sua concepção de vida, enfim da cultura que representam.

Idêntico papel desempenharam os colégios e seminários nas mãos de frades e freiras francesas. Era hábito na Paulistânia da segunda metade do século XIX que as moças estudassem em casa. Entretanto, alguns colégios iam surgindo. Além de alguns existentes na capital, fundou-se nessa época em Itú, um colégio que teve

(66). - Ibidem, pg. XXXIV.
$(66)$. Vide o que a êsse respeito diz Charies Expilly, op. cit., pg. 264.
$(67)$. Maria Paes de Barros, Tempos de dantes. Editôra Brasiliense. 1946, pg. 18. 
grande repercussão nos meios paulistas: o Colégio do Patrocínio, das Irmãs de São José.

Êste colégio foi criado em 1858 em Itú, por irmãs oriundas de Chambery (Savóia), vindas a chamado do bispo D. Antônio Joaquim de Melo, por intermédio dos capuchinhos do Seminário Episcopal de São Paulo, também originários de Chambery, e que aqui se achavam já há alguns anos.

Muitas moças de boas famílias paulistas passaram nesse colégio boa parte de sua meninice. Aí formaram sua personalidade sob a direção dessas irmãs. Os programas de estudos e a orientação do ensino eram dados pela superiora - Madre Teodora (68). Num curso de 7 anos aprendiam as alunas: caligrafia (francesa logo se vê), geografia, história, francês, aritmética, geometria e histôria natural, num curriculum muito semelhante ao adotado em França nessa mesma época. Além. dessas matérias, aprendia-se coisas mais práticas como: trabalhos de agulhas, trico:, crochet, etc... As irmãs não perdiam oportunidade para ensinar bons costumes e as tradicionais maneiras francesas. Nos recreios era costume as alunas cantarem em "brinquedos de roda" canções tìpicamente francesas como Frére Jacques, Au clait de la lune, Il était une bergère qui gardait ses moutons, Malbourough s'en va t'en guerre, Sur le pont d'Avigrion, etc. Essas canções aprendidas na infância, serviram depois de baladas de ninar, que aquelas meninas, então já moças, cantaram para seus filhos. Para encher as horas de lazer, podiam as alunas comprar livrọs de história, como Le livre de la jeune fille en vacance, e muitos outros que faziam sucesso entre elas. Êsses livros, na quase totalidade francesa, por essa mesma época deliciavam as crianças em França.

Alguns anos depois da fundação do Colégio do Patrocínio, as mesmas irmãs de São José fundaram outro colégio semelhante ao primeiro, em Taubaté: o Colégio do Bom Conselho e antes do fim do século um em Franca e outro no bairro de Santana, em São Pau1o. As jovens formadas nesses colégios vivendo num amiente onde se respirava de manhã à noite a cultura francesa, impregnavam-se dela.

Referimo-nos aos franciscanos que tinham fundado um seminário em São Paulo alguns anos antes da chegada das Irmãs de São José e que haviam sido indiretamente os responsáveis pela sua vinda. Foram êles também ativos propagadores da cultura francesa no meio paulista. No seminário que fundaram eram aceitos não sòmente meninos que pretendiam seguir a carreira religiosa, como outros alunos que quisessem apenas instruir-se.

Permaneceram êsses capuchinhos até 1870 mais ou menos, quando em virtude de um escândalo havido com um dos frades, retiraram-se para a França. Esses frades logo que aqui chegaram fizeram correr fama da sua grande ilustração. Sob a sua orientação

(68). - Madre Maria Teodora Voiron, natural também de Chambéry. 
formaram-se muitos rapazes que mais tarde continuaram seus estudos na Academia de Direito, ou em outras escolas do Brasil, mas que levaram para sempre a marca da influência francesa (69). Dos seminaristas que com êles estudaram, sairam sacerdotes notáveis pelo seu extraordinário saber, assim como grandes oradores. Basta citarmos dois dos mais conhecidos - o Padre Chico e o Cônego Manuel Vicente (70).

Não só os que estudaram diretamente sob a direção de professôres franceses sentiram essa influência. Indiretamente, através quer do programa de estudos inspirado no curriculum das escolas francesas, quer dos livros didáticos usados, todos traduzidos de mestres franceses (71), ela atuou mesmo sôbre aquêles que cursaram colégios leigos e tiveram professôres brasileiros.

À língua francesa era sempre dado um especial destaque em todos os estudos. O interêsse despertado por ela na sociedade paulista foi tal que em quase tôdas as famílias entendia-se perfeitamente o francês, quando não se falava correntemente essa língua (72).

Atestam isso os viajantes que aqui estiveram na segunda metade do século XIX e que se admiravam ao encontrar freqüentemente, mesmo no interior das províncias e em vilarejos perdidos no meio de florestas virgens, alguém que era capaz de manter com êles uma longa "prosa" na sua língua pátria e que lhes mostrava uma biblioteca onde figuravam muitos dos mestres da literatura francesa (73).

Observa o viajante francês Adolphe D'Assier em 1867: Ici la langue française s'est introduite elle même comme au XVIII siècle, elle s'introduisait a Saint Petersbourg, comme jadis le grec penetrait a Rome. Elle fait a cette heure partie integrante de l'education brésilienne (74).

O conhecimento da língua pôs á disposição do brasileiro tôda a literatura. As obras francesas de jurisprudência, de anatomia, de cirurgia, encontravam-se nas mãos de alunos da Faculdade de Direito de Pernambuco ou de São Paulo, da escola de $\mathrm{Me}$ dicina da Bahia ou do Rio de Janeiro.

Não havendo em português livros de ciência ou filosofia, a única solução era recorrer-se aos livros franceses. Por isso, professôres da Academia de Direito de São Paulo, como Francisco de

(69): - Manuscrito de obra nāo pubiicada de Emilia Abranches Viotti, Recordaçōes.

(70). - A biblioteca dêsses frades, constituída das melhores obras francesas, quando êles se retiraram foi doada à Faculdade de Direito, segundo informa Daniel Kidder em sua obra já citada à pr. 189.

(71). - O programa de estudos nas escolas brasileiras foi , até mais ou menos 1930 , colocado nos moldes franceses. A propósito dos livros didáticos vide D'Assier (op. cit., pg. 263): dans les collèges la plupart des livres elementaires sont traduits de nos auteurs classiques.

(72). - Maria Paes de Barros atesta êsse fato em sua obra já citada, pg. 18 onde diz: "Grande e pequenos, todos no sobrado falavam francês. Também eram nessa lingua os livros didáticos bem como os volumes das duas estantes que se viam na espaçosa sala de estudos".

(73). Adolphe d'Assier, op. cit., pg. 263.

(74). Ibidem, pg. 263 . 
Paula Belfort Duarte, liam assiduamente as Horas de Trabalho de Pelletan, a Democracia na América de Tocqueville, os Tratados sôbre Politica Geral e Economia Política, de Baudrillart, etc. (75).

O ccmércio dos livros aliás era em todo o Brasil, quase um monopólio dos franceses (76). Os livros vinham à sua escôlha (77). Predominavam, nestas condições, nas bibliotecas dos homens da época, os livros franceses. Já era assim desde os fins do século XVIII em Minas quando entre as obras do Cônego Luiz Vieira da Silva encontraram-se obras de Boussuet, Raynal, Metreagan, La Potière, Joseph Lafitau, Descartes, Condillac, etc. (79) ou na Bahia já no princípio do século XIX, quando entre as obras de Sabino Vieira, ilustre médico e agitador liberal em 1837, assinalaram-se as obras de Montesquieu, Tocqueville, Mignet, Rousseau etc. (79).

Se a aceitação do livro francês é grande já nos fins do século XVIII, acentuou-se mais ainda na segunda metade do sézulo $\mathrm{XIX}$. Os anúncios de leilões, publicados em São Paulo nos jornais de então, demonstram claramente a predominância de obras francesas nas bibliotecas de tempo. Assim é que no anúncio de leilão publicado aos 14 de março de 1878 no Correio Paulistano, chama - leilceiro atenção para os seguintes autores que se destacavam entre outros: Dumont, Le Sage, Say, Lamartine, Michelet, Pelletan, Tccqueville, Villemain, Hugo, Descartes, Victor Cousin, Dumas Fils, Millevoie, Bossuet, etc. Lista que mais parece da biblioteca de um honnête homme do fim do reinadc de Napoleão III ou da 3a. República.

Através dêsses anúncios que são publicados freqüentemente nos jornais paulistas da segunda metade do século XIX, penetramos nas bibliotecas de então. "A literatura francesa, e só ela no que diz respeito a filósofos moralistas e políticos, está aí abundantemente representada" diz Caio Prado Júnior ( 80$)$.

Os livreiros aqui radicados recebiam os livrcs franceses e apressavam-se em anunciá-los ao público letrado. Pelas novidades literárias recém-chegadas, divisamos o iriterêsse que dominava os espiritos, nessa época. A livraria Popular anuncia em 17 de novembro de 1878 no Correio Paulistano, as novidades literárias recém-chegadas: Patric Larrcque, Religion et Politique, 1878; Strauss, Six Conférences, ouvrage traduit de l'allemand; Herbert

\footnotetext{
(75). - Spencer Vampré, Memórias para a história da Academia de São Paulo, Editôra Saraiva Cia. 1924, 2." volume, pg. 82 .

(76). - Mario de Lima Barbosa, op. cit., pg. 417.

(77). - Ibidem - "Les livres venainet au choix des français, la France donnait les idées, qui furent de tant influence sur la formation du Brésil..." (pg. 417).

(78). - Caio Prado Jr. op. cit.. pg. 376, assinala a predominância no fim do século XVIII da literatura francesa entre nós. "A leitura de nossos avós, a parca leitura que se fazia nésta colónia de analfabetos em que só um punhado de pesscas sabia ler e dêstes muito poucos se ocupavam com coisas do espírito, é quase tôda de origem ou inspiração francesa".

(79). - Eduardo Frieiro. op. cit.

(80), - Caio Prado Jr., Formação do Brasil Contemporyneo, pg. 376.
} 
Spencer, De l'éducation intelectuelle, morale et physique (traduit de l'anglais), París. Flammarion 1878; Les terres du Ciel; Jacaliot, Roi prêtes et Castes, París, 1877; Idem, Les pariah dans l'humianité; idem, Fetichisme, Politheisme et Monotheisme; Renan, L'évangile, 1877; Hartmann, Le darwinisme, ce qu'il y a de vrai et de faux dans cette théorie; Paul Janet, Saint Simon et le Simonisme; Taine, Philosophie de l'art en Italie; Albert Reville, Histoire du dogme de la divinté de Jésus IChrist; e outras obras de Stuart Mill, Belot, Daudet, Zola, Octave Feuillet, Victor Hugo, etc.

Anúncio semelhante aparece no Correio Paulistano de 1o. de março de 1878, onde a Casa Garraux faz saber ao público a recente chegada de livros modernos. Outros autores, então em moda, aí estão: Emile Accolas, Science Politique; Albert Babeua, Le village sous l'ancien régime; Victor Borie, Chaix d'est Ange, etc. Livrcs técnicos também aparecem em grande número, como os de Charcot, livros sôbre moléstias do fígado de Camille Darest; Dr. Isamber, maladies de Laringe; Jousset, Leçon de Clinique Médicale; Dr. Oré, Le chloral et la medication intra-veineuse, etc. Inúmeros livros de Direito, de Dupont, Didier, Pailhé, etc., e uma série de outros volumes de história, geografia, romances, livros de viagem e filosofia (81).

Mesmo os que moravam no interior da Província estavam sempre a par das últimas novidades literárias, que thes enviavam os livreiros amigos (82).

Os livros franceses imperavam soberanos! Ao seu lado tìmidamente aparecia uma ou outra obra de autor português ou nacional.

A língua francesa foi também o veículo de que se serviu o brasileiro para penetrar em outras culturas, como a inglêsa ou alemã. Muitas obras de autores inglêses (83) ou alemães, chegaram até nós traduzidas para o francês. Entretanto, é quase exclusivamente na literatura francesa que vai o paulista da segunda metade do século XIX buscar informaçõ̃es que enriqueçam seus conhecimentos e que satisfaçam seus desejos de saber.

Franceses eram os livros que os mestres e estudiosos de matemática, história, geografia, medicina ou direito, utilizavam nos seus estudos. Francesas também eram as obras que distraiam o espírito, nas horas em que a mente cançada procurava fugir à rotina diária, mergulhando numa outra vida - no mundo dos ro-

\footnotetext{
(81). - Fizemos questão de reproduzir aqui, êsses anúncios mesmo com o perigo de nos tornamos maçantes, pelo alto significado que pode ter essa longa enumeraçāo, que reflate o interêsse da época. E' nesse mesmo intuito que reproduzimos aqui, mais uma lista de livros, anunciados no Correio $P$ aulistano de 26. 11-1861, onde aparecem livros de história de Thiers, Cantu, Baracroncourt, Mi. chelet, Le Bas e romances de Gerge Sand, Montalambert, Michelet, Lamartine e livros de poesia de Théophile Gautier.

(82). - Amélia Resende Martins, em sua obra citada, assinala que mesmo em sua fazenda, seu pai era um dos primeiros a reseber novidades literárias (pg. 163)

(83). - Veja-se a êsse respeito o prefácio da obra de Gilberto Freyre, Inglêses no Brasit, pg. 17 .
} 
mances e da poesia. Não faltavam nas bibliotecas de um homem medianamente culto da segunda metade do século XIX obras de Corneille, Racine, Voltaire, Rousseau, Mme. de Sévigné, Montesquieu, La Fontaine, Lamartine, Chateaubriand, Lacordaire, Coppé, Théophile Gautier, Octave Feuillet, Victor Hugo, Balzac, Mme. de Stäel, George Sand, Feval, Zola, Flaubert, etc. (84).

Revistas e jornais franceses obtinham grande aceitação na sociedade paulistana. A Revue des Deux Mondes e I"Illustration, eram as preferidas (85). A Casa Garraux em anúncio transcrito no Corteio Paulistano aos 5 de janeiro de 1871 , fazia saber ao público que aceitava assinaturas para jornais e revistas européias (o que no caso queria dizer francesas). Entre as revistas mencionadas destacam-se: Mode Illustré, Conseiller des Dames et des Demoiselles, Magasin des Demoiselles, Moniteur des dames et des Demoiselles, Modes Française, Monde Illustré, Univers Illustré, Illustration, Revue des Deux Mondes, etc. Entre os jornais: Gazete des Hopitaux, Gazette Médicale, Gaulois (jornal político, noticioso, literário), Figaro (idem) Courrier de l'Europe, Moniteur des architects, Revue critique de Jurisprudence, etc.

Nítida a predominância de revistas de modas; mas não era apenas nesse campo que os paulistas buscavam inspiração nas revistas francesas. Também no setor técnico, como bem o indica a presença de revistas e jornais que tratam de assuntos de medicina, arquitetura e direito. O paulista, ligado cultural e sentimeutalmente à Europa, pela França, interessa-se pelos acontecimentos que se passam no mundo europeu, e não satisfeito com o noticiário minguado de seus periódicos, vai saciar sua curiosidade nas re-vistas e jornais franceses.

A influência pois, da língua e literatura sob a forma de livros jornais e revistas, a favor da irradiação da cultura francesa entre nós, foi enorme. Franceses eram os compêndios em que se estudava, os romances que se liam, os filóscfos que orientavam os conceitos; os livros técnicos de medicina, direito ou arquitetura, onde ia o intelectual buscar inspiração; francesas as revistas e mesmo alguns jornais. Não podemos esquecer, entretanto, que a ação dêsses agentes: livros, jornais e revistas, por mais difundida que tenha sido, esteve sempre circunscrita a um grupo relativamente limitado de pessoas - de uma certa cultura, a elite -não exercendo grande influência sôbre a massa do povo.

(84). - Esses livros constavam das biblioteca de Frederico Abranches Viotti, que viveu entre 1840 e 1900. Dêles tomei conhecimento através de uma lista que me forneceu sua filha. Além dêsses romancistas e poetas, figurava nela uma

1 série enorme de livros diréito, história, ciências, etc., todos em francés. Numa pesquisa que fizemos em outras bibliotecas do tempo, pudemos constatar êsse dominio.

(85). - Maria Paes de Barros nos fala em sua obra, pg. 18, de uma outra revista: L'Echo des Feuilletons, que era assinada em sua casa. 
Outro fator divulgador de cultura francesa entre nós, foi o teatro. Sua ação, só se fêz sentir tardiamente, já no fim do século XIX, depois do grande impulso tomado pela lavoura cafeeira, quando a sociedade paulista se refinando e se enriquecendo, tcrna-se cada vez mais exigente em matéria de diversão. E'. nessa ccasião que o público paulista assiste a representações de grandes companhias como a de Sarah Bernhardt ou Coquelin (86).

$O$ papel de divulgador da cultura francesa desempenhado pelo teatro, ficou limitado ao âmbito das platéias, e não teve como agente difusor a importância das casas de ensino, dos professôres, dos artesões e mesmo dos livros.

$\mathrm{Na}$ análise da maneira pela qual se processou a influência francesa em São Paulo na ségunda metade do século XIX, vimos a atuação que tivẹram, as casas de comércio, os artesões, os professôres, colégios, os livros, revistas e jornais, e o teatro, como agentes da cultura francesa entre nós. Nesse sentido foi também importante o papel das missões culturais, dos viajantes franceses que percorreram o Brasil nessa ocasião, e principalmente dos técnicos contratados.

A ciência, a literatura e a arte francesa, enviaram até nós notáveis representantes. Foi a missão artística de 1816, com Grandjean de Montigny, Ferrez, Taunay, Debret, Lebreton, Pradier e outros, o primeiro passo oficial nesse sentido. A êsses seguiram-se muitos outros: Saint-Hilaire, Castelnau, Tollenare, Ribeyrolles, D'Assier, Expilly, Debadie, d'Orbigny e inúmeros outros viajantes, dignos representantes da cultura francesa, que percorreram o Brasil e deixaram ampla documentação acêrca da nossa história, geografia e etnografia.

"Quase tôdas essas obras francesas sôbre o Brasil inäicam que à presença em nosso país, de seus autores, correspondeu, luma ação ou influência de idéias, estilos e maneiras francesas, trazidas por êles. Ação senão ostensivamente pedagógica, como a dos mestres franceses no período de D. João VI e ncs primeiros tempos do império, pelo menos estimulante" (87).

Os técnicos contratados e as missões culturais que aqui estiveram a convite do govêrno, contribuiram mais do que êsses viajantes, que por aqui passaram ràpidamente, para dar a São Paulo uma orientação moldada nos hábitos e na experiência francesa.

Inúmeras missōes francesas vieram orientar os paulistas. Até mesmo uma missão militar aqui esteve chefiada por Paul Balagny, em 1906, para instruir e reestruturar a milícia paulista, organizando a Fôrça Pública.

\footnotetext{
(86). - Mario de Lima Barbosa, op. cit., pg. 425, diz: Les Brésiliens aiment le théâtre en beneral, mais leur delection est un previlège du théatre français que les a eduqué et a formé leur gout, au cours de cette leçon traditionnelle commencé avec Coquelin, Suzanne Desprez, Le Bargy, Réjanne, Antoine, Lucien Guitry, deux Coquelin, Suzanne Desprez, Le Bargy, Réjamnne, Antoine, Lucien Guitry, Jena Hoding, Georkes Grand, Jeanna Provost, Gabrielle Dorziat, etc...".

(87). - Gilberto Freyre, $U m$ engenheiro francês no Brasil, pg. 33.
} 
Os muitos técnicos contratados pelo govêrno, foram verdadeiros focos de difusão da cultura francesa, na pequena sociedade paulista da segunda metade do século XIX. Sua influência não se cestringiu apenas ao campo referente à técnica em que eram especialistas: ensino, engenharia, arte militar, etc., mas estendia-se sôbre as idéias, os sentimentos, os hábitos, a vida íntima e social dessa época.

As viagens de recreio ou de estudo que os paulistas faziam à Europa, e principalmente à França, contribuiram para o mesmo resultadc. Tornara-se hábito entre as famílias de grandes posses enviarem seus filhos para completarem seus estudos nas Universidades francesas. Esses jovens formavam seu intelecto na Franç, $e$ adaptavam-se durante os anos de estudos aos costumes fianceses. Ao voltarem à pátria, traziam tôda uma série de hábitos profundamente enraizados. Sua mentalidade sofrera a pressão dos moldes franceses, formara-se sob o calor dessa cultura, ficara marcada para o resto da vida. O método francês tornara-se o seu método. Passaram êles a ocupar no meio em que viviam a posição de divulgadores da cultura francesa.

As viagens de recreio que os paulistas faziam à Europa, quase que anualmente, agiram de maneira semelhante, se bem que com muito menor intensidade. Em São Paulo essas viagens tornaram-se um hábito chic entre as famílias ricas, na segunda metade do século XIX, mas foi com o sempre crescente desenvolvimento da cultura cafeeira e com o conseqüente enriquecimento de muita gente, que elas se tornaram uma verdadeira obrigação. Anualmente muitas famílias paulistas transportavam-se com todos os seus membros para a França, onde permaneciam durante alguns meses (88). De volta, faziam êles numerosas compras, e sem perceberem, aquisições novas de hábitos e idéias assimilados quase inconcientemente. Esses contactos com a Europa, renovados frequientemente nessa época, foram úteis para a divulgação da cultura francesa, num determinado meio social paulista.

$$
\begin{aligned}
& \text { :4 } \\
& * \quad
\end{aligned}
$$

Por interméđio dos variados agentes: artesões, comerciantes, artigos, livros, revistas, jornais, colégios, professôres, governantes, artistas, missões culturais, viajantes de proveniência francesa, técnicos contratados, viagens de estudo ou de recreio à França, firmou-se entre nós, de modo acentuado a influência da cultura e da técnica francesa. Cada um dêsses fatôres agiu à sua maneira e com intensidade diversa sôbre a sociedađe paulista. Essa influên-

(88). - Amélia Resente Martins, $U m$ idealista realizador, pg. $67,77,498$ segs., 633 e sgs. 
cia estendeu-se nessa época, pela diversidade de agentes a todos os setores e manifestou-se em todos os campos: nas coisas materiais e imateriais, nas modas, na literatura, na casa, na filosofia, na alimentação, no folclore, etc. Não se pode esquecer entretanto que ela esteve pràticamente restrita a um certo grupo social cuja educação (grau de cultura) e situação econômica facilitaram os contactos com os agentes divulgadores dessa cultura.

No mobiliário (89), nos enfeites e quadros que adornam a casa de pessoas de um certo nível social, manifesta-se nesse fim do século XIX a influência francesa. Gravuras de François Delarue, publicadas em París, povoam as paredes. Estatuetas, vasos de Sévres, enfeitam os recantos da casa. Sôbre os móveis, albuns de fotografia ricamente encadernados, vindos diretamente de $\mathrm{Pa}$ rís, guardam preciosos retratos de tôda uma geração. As paredes internas já não são mais pintadas como no tempo que Saint $\mathrm{Hi}$ laire visitara São Paulo, finíssimos papéis estampados importados diretamente da França recobrem-nas inteiramente. A louça de Sèvres vem substituir a louça portuguêsa ou a de Macau de épocas anteriores. $E^{\prime}$ em aparelhos finíssimos de Sèvres que as famílias mais abastadas tomam suas refeições. Algumas vêzes adamascados vindos de París, cobrem as mesas (90). Talheres de cristofle completam o quadro. Em algumas residências mais ricas até as maçanetas de cristal são importadas (91). Também os jardins, principalmente os das chácaras nos arredores de São Paulo, demonstram no seu planejamento e desênho, a influência dos mestres franceses: jardineiros que estiveram durante longos anos fazendo os jardins brasileiros "à moda francesa", resultando dessa tentativa um produto híbrido assás curioso, mais tarde remodelados segundo os moldes britânicos e ianquis. Provàvelmente também a alimentação se ressentiu da influência dos numerosos cozinheiros franceses aqui radicados. Quantos pratos novos devem ter sido introduzidos no cardápio e terão ficado definitivamente integrados na nossa alimentação?! Iguarias e vinhos franceses são durante tôda essa época largamente importados: Champagne Aye, vinhos de Bordéus, Borgonha, queijos franceses, etc., figuravam na mesa de muito paulista rico.

Ao lado dos produtos alimentícios os objetos de uso como: caixas de costura, papéis de carta, fazendas, roupas, brinquedos mostram nítida influência gaulesa.

Os penteados feitos pelos cabelereiros franceses obedecem a estrita regra parisiense, e os perfumes consumidos vem também de lá. A moda francesa é ditadora absoluta no que diz respeito ao traje feminino: sapatos, vestidos, roupa branca, luvas, chapéus, tu-

(89). - Clado Ribeiro Lessa, o mobiliário brasileiro nos tempos coloniais, in Estudos Brasileiros, n. 6, Ano I, pg. 15 e 16.

(90). - Amélia Resente Martins, op. cit., pg. 350.

(91). - Ibidem, pg. 350 
do obedece a suas regras.. A mulher paulista de uma certa classe veste-se e calça-se de acôrdo ccm a moda parisiense.

Se a mulher é mais escrava da moda parisiense que o homem, êle também a obedece. São êsses homens que por volta de 1860 , usam românticas melenas a Alfred Musset, ou a Théophile Gautier e barba a Napoleão III (92) e vestem-se no Pedro Bourgade ou no Henri Scecerpelle, segundo os figurinos de París e que muitas vêzes se chamam: Danton, Lafayete, Luiz Felipe, Lamartine, Voltaire, Napoleão (93).

Até mesmo a arquitetura manifesta a influência de franceses como o arquiteto Charles Peyrouton. Foi um dêles, Jules Martin, estabelecido com litcgrafia em São Paulo na segunda metade do século XIX, o idealizador do Viaduto do Chá (94).

Quantos traços da preponderância francesa impressos na paisagem! Se é difícil acompanhar as provas materiais da influência francesa, mais ainda será assinalá-la no campo intelectual onde ela manifestou mais importante e duradoura.

São os novos galicismos, é o folclore (95) enriquecido, é o declínio rápido e o quase abandôno das modinhas e dos lundús tão brasileiras, substituidas pelas canções e valsas francesas (96). No ensino, no pensamento religioso (97), filosófico (98), literário, político, na arte, há sinais evidentes da assimilação cultural, assinala-se a influência de es:olas e tecrias francesas. Quantas formas importadas!

Esse fenômeno não se restringe ao cenário paulista: tem caráter nacional. Essa influência não se limitou apenas aos núcleos urbanos, embora nestes tenha sido, provàvelmente, mais intensa . Atingiu mesmo as zonas rurais onde imperou em muitos solares de grandes fazendas - quer da Baixada de Campos, do Vale do Paraíba, do Centro e Oeste paulista, ou do Nordeste. Mas o que não se pode esquecer é que ela atuou sobretudo num grupo de elite - no sentido mais amplo e flexível da palavra: econômico, social ou intelectual.

O estudo da marcha dessa influência e dos seus resultados é um elemento a mais para a compreensão das manifestações lite.

\footnotetext{
(92). Spencer Vampré, op. cit., pg. $67,2^{\circ}$ volume.

(93). - A lista de alunos que cursavam a Faculdade de Direito nessa época bem demonstra isso, basta que leiamos Almeida Nogueira, op. cit., ou Spencer Vampré para o constatarmos. Igual fenômeno é assinalado por $G$. Freyre em $U m$ engenheiro francés no Brasil, pg. 40

(94). - Paulo Cursino de Moura, op. cit., pg. 101

(95). - Santana Nery, Folclore Brésilien. París, 1889. Berrin 8 Cie. Librarie Editeurs. diz: Plusicurs de nos jeu d'enfants quelques chants qui les accompangnent, presentent des analogies frappantes non seulement avec ceux de Portugal, ce qui est tout natureile, mais encore avec ceux de France.

(96). - Ibidem, pg. 72

(97). - Foi grande a influência religiosa francesa em São Paulo. Até mesmo os santos "em moda" eram na segunda metade do século XIX, santos franceses: como Santa Joana de Chantal e Nossa Senhora de Lourdes.

(98). - A filosofia de Augusto Comte encontrou em São Paulo um campo fertil para seu desenvolvimento. Por sua vez Joseph de Maistre, De Bonald e Benjamin Constant fcram os oráculos sempre invocados pela reação anti-liberal.
} 
rárias, políticas e ideológicas do Segundo Império e da primeira República. Pensamos, por exemplo, na explicação da disponibilidade de certos espíritos para com o movimento republicano po: volta de 1870-1873, quando os nossos políticos. se correspondiam com Gambetta e citavam teoristas franceses. Ou ainda, na tão propalada influência da Inglaterra na organização política do $\mathrm{Br}$ sil imperial, que nos leva a imaginar, quando deparamos nas bibliotecas dos homens do tempo, uma bibliografia onde há, de uma maneira geral, uma predominância quase absoluta de autores fran. ceses, que a fonte de inspiração dos nossos políticos muitas vêzes êsses autores franceses, também impregnados como estavam de admiração pelo sistema inglês e cujas obras por isso mesmo, eram. cheias de citações de autores e exemplos inglêses. E neste caso tratar-se-ia de mais um exemplo da influência francesa no Brasil, do que pròpriamente da britânica. Tudo são reflexões a esmo. O que é certo é que algumás idéias e atitudes dêsses homens do tempo, que conviviam tão ìntimamente com as coisas e idéias francesas são de maneira evidente produtos de importação, nesse Brasil do Império e da Primeira República, ainda em grande parte, uma colônia espiritual da Europa e principalmente da França.

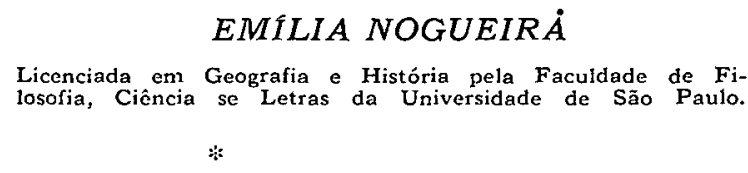

BIBLIOGRAFIA UTILIZADA

BARBOSA (M. Lima). - Les Français dans l'histoire du Brésil. Rio de Janeiro, F: Briguet et Cis. Editeurs. Tarís. Libraririe Scientifique Blanchard.

BARROS (Maria Paes de). - No tempo de Dantes, Editôra Brasilense, 1946.

CALMON (Pedro). - História Sacial do Brasil. 3 volumes. Companhia Editồra Nacional. 3a. edição.

D'ASSIER (Adolphe). - Le Brésil Contemporain. Paris. 1867. Durand et Lauriel.

DEBRET (J. Baptiste). - Viag:m pitoresca e histórica do Brasil. Livraria Martins Editôra.

DENIS Ferdinand). - Le Brésil ou histoire des moeurs, usages et coutumes des habitans de ce roy royaume.' 5 volumes. Paris. 1822.

EXPILLY (Charles). - Le Brésil tel qu'il est. E. Den. Editeurs. Paris. 1862.

FREITAS (Afoniso de). - Tradições e Reminicências. Monteiro Lobato \& Cia. Editôra. 1921. 
FREYRE (Gilberto). - Sobrados e Mucambos. Companlia Editôra Nacional, 1936 (Brasiliana). Um engenheiro francês no Brasil. Livraria José Olímpio Editôra. 1940. Inglêses no Brasil, Livraria Jơsé Olímpio Editôra. 1948.

FRIEIRO (Eduardo). - O diabo na livraria do Cônego. Livraria Cultura Brasileira Ltda. Belo-Horizonte.

HILAURE (Saint). - São Paulo nos tempos coloniais. Monteiro Lobato \& Cia. Editôra. 1921. Segunda viagem ao Rio de Janeiro. Minas Gerais e São Paulo.

KIDDER (Daniel). - Reminicência da viagem e permanência no Brasil (Rio de Janeiro e Província d’ São Paulo). Livraria Martins Editôra.

KOSERITZ (Karl von). - Imagens do Brasil. Livraria Martins Editôra. 2 volumes.

LEVASSEUR. - Le Brésil. Lamiraut \& Cia. Editeurs. Paris. 1889.

MARTINS (Amélia de Resende). - Um idealista realizador. Baräo Geraldò de Rezende. Oficinas Gráficas do Almanaque Laemmert. 1939 .

MARTINS (Antônio E. ). - São Paulo Antigo. 2 volumes.' Típografia do Diário Oficial. 1912

MORAIS FILHO A. Mello). - Fatos e Memórias. Livraria Editôra Ganicr. 1904.

MOURA (P. Cursino de). - São Paulo de Outrora, evocações da Metrópole. Livraria Martins Editôra. 1943, 2a. ediçăo.

NERY (Santana). - Le Brésil em 1889. Paris Librariz Ch. Delagrave. Folklc:e Brésidien. Perrin et Cie. Libraries Editeurs: Patris 1889 .

NOGUEIRA (Almeida). - A Academia de São Paulo. Tradições e reminicências. Estudantes, Estudantadas. 1907. Tipografia Vanorden. 8 volumes.

PINHO (Wanderley). - Salórs e Damas do 2.0 Reinado. Livraria Martins Editôra 2a. edição.

PRADO JR. (Caio). - Formação do Brasil Contemporàneo: Colònia. 3a. edição. Editôra Brasiliense. 1948.

RIOS (Morales de los). - O Rio de Janeiro Imperial. Editôra "A Noite', 1946.

RIBEYROLLES - (Charles). - Brasil Pitoresco. Livraria Martins Editôra.

SIMON (Mme. Toussaint). - Viagem de uma parisienso ao Brasil. Tradução. Rio de Janeiro. 1883. Tip. Imp. e Const. de J. Villeneuve.

SODRE' (Nelson Werneck). - Panorama do Brasil no Segundo Império.

SOUZA (Otávio Tarquínio). - Evaristo da Veiga. (Brasiliana) 1939. Comp. Editôra Nacional. 
TAUNAY (Visconde de). - Estrangeiros ilustres e prestimosos no Brasil. Editôra Companhia Melhoramentos de São Paulo.

VAMTRE' (Spencer). - Memórias para a história da Academia de São Paulo. Saraiva \& Cia. Editôra. 1924 (2 volumes).

ZaLUaR (Emílio). - Peregrinação pela Prcvíncia de São Paulo.

Revista do Institutc. Histórico e Geográfico de São Paulo. Volumes 6, 14 e 19. Afonso de Freitas. A imprensa paulista.

Teodcro Sampaio, Sâo Paulo no século XIX.

Eugenio Egas, São Paulo - a cidacie.

Estudos Brasileiros, $n .{ }^{\circ} 6$.

Clado Ribeiro Lessa, $\mathbf{O}$ mobiliáric brasileiro nos tempos caloniais.

Almanaque de São Paulo de 1884.

Correio Paulistano: Ano de 1878 - Janeiro a dezmmbro.

Ano de 1871 - Janeiro a julho.

Ano de 1854 - 17 de novembro.

Ano de $1861-2 \vec{t}$ de setembro.

Digesto Econômico - Artigos - Tarquínio de Souza .

Sôbre Influência francesa no Brasil.

Nov. 1948 - Dez. 1948 - Jan. 1949 - Fev. 1949.

Ms. - Emília Abranches Viotti, Recordações. 